\title{
Modern Outlook on the Nature of Money
}

\author{
Galina Sergeevna Panova* \\ Moscow State Institute of International Relations of the Ministry of Foreign Affairs of the Russian Federation \\ (MGIMO), Moscow, Russia; monblan@yandex.ru
}

\begin{abstract}
The article considers the current issues of the nature of money, the state and development prospects of money circulation. The author conducted the comparative analysis of Russian and foreign researchers' opinions on the nature of money today. Besides, the article defines the place and role of electronic money in the total money turnover and considers the issues regarding the transformation of the global financial credit system. The author proposes the position according to which the phenomenon of electronic money demonstrates that the nature of money is not limited to their material form, but, more importantly, is characterized by its ability to perform certain functions. The article advises on developing international standards for the regulation of the electronic money circulation since its use is a relatively new practice - a prototype of a fundamentally new monetary system. The article emphasizes that the development of electronic payment systems should be subject to financial regulation. In countries with a developed economy and stable monetary system electronic money will occupy its niche, where it can be used most effectively, while its implementation should be more strictly regulated in developing countries.
\end{abstract}

Keywords: Bitcoins, Cash and Non-Cash Money, Cryptocurrencies, Full Bodied and Token Money, Money Turnover

\section{Introduction}

Over the past 30 years Russia has tried virtually a whole range of measures aimed at stabilization of the money circulation, including monetary reforms that are defined by us as a full or partial transformation of the monetary system carried out by the state in order to rationalize and strengthen the money turnover.

However, in the age of globalization and IT one cannot address the issues dealing with the stability of the national currency and the monetary system of the country without taking into account the state and development trends of the global economy.

The global financial system is "drifting" from the system uniting national monetary systems, based on national currencies, to a multi-currency system which uses advanced information technologies and modern computers. It's no coincidence that the global community is actively discussing the phenomenon of electronic money and cryptocurrency. In this regard, the answer to the question on the nature of modern money, from our point of view, is to be found through investigating the dynamics of the money turnover.

\section{Literature Review}

The history of the mankind demonstrates that the money is continuously developing. In historical perspective the evolution of money forms and types can be conventionally represented as a gradual transition from commodity money to electronic money.

$\begin{array}{lccc}\begin{array}{l}\text { Commodity } \\ \text { money } \\ \text { (money functions }\end{array} & \text { Metal money } & \text { Paper money } & \begin{array}{c}\text { Elec- } \\ \text { tronic }\end{array} \\ \begin{array}{l}\text { performed by vari- } \\ \text { ous goods) }\end{array} & \begin{array}{c}\text { Transfer to } \\ \text { of a universal } \\ \text { equivalent }\end{array} & \begin{array}{c}\text { credit and } \\ \text { then paper }\end{array} & \\ & \text { money } & \end{array}$

\footnotetext{
${ }^{*}$ Author for correspondence
} 
Certain types of goods, used in the exchange as equivalents, may be called the predecessors of money. Commodity money appeared on the stage of emerging commodity-money relations, when some equivalent items and media of exchange appeared as a result of evolution (Table 1). Despite their shortcomings, commodity money had been used for thousands of years.

Table 1. Commodity money used as a medium of exchange

\begin{tabular}{ll}
\hline Agate (Borneo) & $\begin{array}{l}\text { Mats, straw mats } \\
\text { (Hebrides) }\end{array}$ \\
$\begin{array}{l}\text { Fish bones (Indochina) } \\
\text { Surma powder (Central Sudan) }\end{array}$ & $\begin{array}{l}\text { Bark of the mulberry tree } \\
\text { (Polynesia) } \\
\text { Mussels (Pacific Ocean) }\end{array}$ \\
Axes (Congo) & Needles (Gold Coast) \\
Grain (Egypt) & Nephritis (Caribbean) \\
Butter pellets (Tibet) & Opium (Hainan) \\
Dates (Siwa Oasis) & Pearl (New Guinea) \\
Groundnuts (Nigeria) & Peppers (Peru) \\
Feathers (Melanesia) & Rice (Korea) \\
Dried fish (Iceland) (Melanesia) & Rum (New South Wales) \\
Fish bones (New Caledonia) & Sago (Eastern Indonesia) \\
Resin balls (Malay Archipelago) & Salt (Abyssinia) \\
Deerskin (China) & Silk (China) \\
Millet (Somalia) & Tea (Mongolia) \\
Camphor (Central Sudan) & Jasper (Ujiji) \\
Cowry Mussels (Siam) & Animal tusks (Fiji Islands) \\
Mahogany wood (Honduras) & Onions (Central Sudan) \\
\hline
\end{tabular}

In modern world people can also use commodity money if there is such a need. Throughout the history, for example, in times of war, revolutions, economic crises and other difficult periods of the society development people tend to resort to barter. In these cases, cigarettes, alcohol (vodka), matches, salt, food in short supply etc., may be used as commodity money in a person-to-person exchange. It is obvious that in the current context the use of commodity money cannot continue for a lengthy period as it is fraught with a serious disorder to the national economy.

Drive for the development of the exchange led to the situation when a universal equivalent was singled out from the whole variety of the commodities. Development of the exchange, its intensity led to the money's gradually turning into a universal equivalent, the material basis of which were the precious metals.

Full bodied money, in fact being a form of commodity money, is: Bullions; coins made from precious metals (mainly gold and silver); banknotes redeemable in precious metals. In fact, the emergence of paper token money, and then electronic money was predetermined by the entire course of the civilization. On the one hand, debasement of coinage has demonstrated that the role of full bodied money can be performed by token money if the government accepts it as a legal means of payment. On the other hand, the widespread loan notes and promissory notes showed that banknotes made from paper can be used as a means of payment.

The current stage of world history is characterized by the rapid development of the financial and banking sector which predetermined the emergence of non-cash money in the form of entries in bank accounts. This non-cash money is currently the predominant form of money, one of its varieties being the electronic money. Cash money is also evolving, gradually separating from its paper form.

Many economists assume that paper money will completely disappear in the future as it will be replaced by the electronic money. Still, the nature of money will remain the same, only its form will change: the money will drift into the sphere of virtual reality - it will become "invisible". The place of electronic money in the modern monetary theory is still debated; however, experience shows that virtual money is becoming the currency of the global economy and its financial markets.

Modern monetary system is actually based on the exchange of token money or money not redeemable in gold. In this regard, economists give the following definition of money. "The nature of money is determined by the functions it performs. Anything can be money as long as it is recognized by people as such and performs its functions". Or: "Money is any conventional means of payment which can be exchanged for goods and services and used to pay debts, one of the two main categories of any commodity economy. Money is an economic category, which embodies and facilitates social relations" ${ }^{2}$. In Russian papers we may find another definition of money: "Money is a special commodity, the universal equivalent, the form representing the value of all other goods" ${ }^{\prime-5}$.

The so-called western outlook on the nature and functions of money which emphasizes the empirical approach is quite popular in economics (Figure 1) $)^{6-7}$.

It is believed that the unit of account has its intrinsic value used to measure the value of goods. "Book" money includes deposits at the central or commercial banks (Giralgeld). All other kinds of money (for example, checks) may be called credit money, it is not fully liquid (making payments on request) and is not completely 


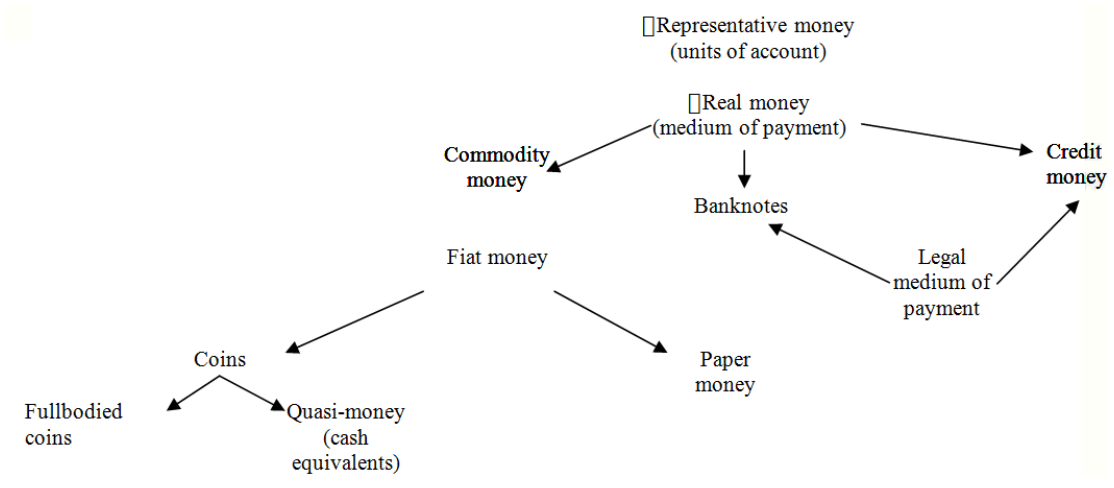

Figure 1. Types of money and their relationships.

Table 2. Classification of money types

\begin{tabular}{|c|c|c|c|c|}
\hline Criterion of classification & \multicolumn{4}{|l|}{ Money types } \\
\hline $\begin{array}{l}\text { Pattern of use (functions } \\
\text { performed) }\end{array}$ & \multicolumn{2}{|c|}{$\begin{array}{l}\text { Real money - material monetary units in the form } \\
\text { of coins and banknotes in the cash money turnover } \\
\text { or on bank accounts in non-cash money turnover; } \\
\text { serves as a medium of exchange, a medium of pay- } \\
\text { ment, store of value. }\end{array}$} & \multicolumn{2}{|c|}{$\begin{array}{l}\text { Ideal money - abstract money (units of } \\
\text { account) - non-material, virtual money, } \\
\text { functions as a measure of value }\end{array}$} \\
\hline $\begin{array}{l}\text { Redeemable in gold or } \\
\text { other precious metal }\end{array}$ & \multicolumn{2}{|c|}{$\begin{array}{l}\text { Full-bodied (or good) money- the money whose } \\
\text { intrinsic value as a commodity is the same as its face } \\
\text { value (gold or bank notes redeemable in gold). }\end{array}$} & \multicolumn{2}{|c|}{$\begin{array}{l}\text { Token (symbolic) money - money whose } \\
\text { intrinsic value is less than its face value (not } \\
\text { redeemable in gold). }\end{array}$} \\
\hline $\begin{array}{l}\text { Liquidity and legal grounds } \\
\text { for circulation }\end{array}$ & \multicolumn{2}{|c|}{$\begin{array}{l}\text { Legal money - money with full liquidity, has a } \\
\text { status of a legal medium of payment. }\end{array}$} & \multicolumn{2}{|c|}{$\begin{array}{l}\text { Illegal money ("quasi-money" or "money } \\
\text { tokens") has partial or limited liquidity. }\end{array}$} \\
\hline Circulation of money & \multicolumn{2}{|c|}{ Cash } & \multicolumn{2}{|c|}{ Non-cash } \\
\hline \multicolumn{5}{|l|}{ - Type of ownership } \\
\hline - Economic entity & $\begin{array}{l}\text { Banks } \\
\text { (issuer - the Central Bank) }\end{array}$ & $\begin{array}{l}\text { Treasury } \\
\text { (issuer - the Ministry } \\
\text { of Finance) }\end{array}$ & Corporative & Others \\
\hline Material form (medium) & Commodity & Metal & Paper & Electronic \\
\hline \multirow[t]{2}{*}{ Area of application } & \multicolumn{4}{|l|}{ Modern fiat money } \\
\hline & Credit money & & \multicolumn{2}{|l|}{ Paper money } \\
\hline Issuer & The central bank & & $\begin{array}{l}\text { The central ba } \\
\text { Finance (Trea }\end{array}$ & Ministry of \\
\hline $\begin{array}{l}\text { The purpose of the issue } \\
\text { (emission) }\end{array}$ & \multirow{2}{*}{\multicolumn{2}{|c|}{$\begin{array}{l}\text { Loans to businesses and population, in accordance } \\
\text { with the normal needs of the economy } \\
\text { Appears due to the loan issue }\end{array}$}} & $\begin{array}{l}\text { Issued to cove } \\
\text { gets of all leve }\end{array}$ & nditures of the bud- \\
\hline Issue type & & & $\begin{array}{l}\text { Issued in circl } \\
\text { creation }\end{array}$ & to the money \\
\hline Cover & \multicolumn{2}{|c|}{$\begin{array}{l}\text { Has a stable or increasing cover in precious metals } \\
\text { and commodities }\end{array}$} & $\begin{array}{l}\text { Does not have } \\
\text { cover) }\end{array}$ & over (decreasing \\
\hline Gold guarantee & \multicolumn{2}{|c|}{$\begin{array}{l}\text { Full-bodied and token money, redeemable and not } \\
\text { redeemable in gold. }\end{array}$} & $\begin{array}{l}\text { Is tokenonly. } \\
\text { Not redeemab }\end{array}$ & \\
\hline Purchasing power & \multicolumn{2}{|c|}{ Stable, does not decrease } & Unstable, dec & \\
\hline $\begin{array}{l}\text { Influence on money } \\
\text { circulation }\end{array}$ & \multicolumn{2}{|c|}{$\begin{array}{l}\text { Is not subject to depreciation or inflation. } \\
\text { Does not overfill the channels of money circulation. }\end{array}$} & $\begin{array}{l}\text { Is subject to d } \\
\text { Overfills the c } \\
\text { with depreciat }\end{array}$ & $\begin{array}{l}\text { n or inflation. } \\
\text { f money circulation } \\
\text { tary units. }\end{array}$ \\
\hline
\end{tabular}


steady (secure). Real money is considered as a medium of payment, while all transactions done with money, involve making payments. Checks, promissory notes, certificates, and sometimes credit agreements are attributed to paper money. In contrast to that, cigarettes, silver coins, banknotes are defined as commodity money ("piece" money).

\section{Methodology}

Analysis of different positions and views on the nature and functions of money allows us to say that types' diversity is a specific feature of modern money. This results, firstly, from the increase in terms of value in the number and volume of ongoing commodity-money transactions. Secondly, a diversity of these operations is increasing, and it enables further differentiation of the forms and types of money. In fact, there is a certain specialization of money while maintaining the interchangeability of its different types, with different types transforming into one another. Summing up the approaches considered above allows us to classify the types of money (Table 2).

\section{Results}

Evolutionary transformation of money types is the result of the natural development of the society. Thus, evolution of money types is facilitated by the technical and scientific progress.

The emergence of a new type of money is an economic necessity, when previous types of money are beginning to slow down the speed of production and exchange, and if there are prerequisites for their emergence. There is a constant search for more efficient financial systems which would help to save the social labor, reduce costs of the money circulation, increase the rate of the turnover, increase security and ease of the money circulation.

David Chaum developed a system of electronic money in the early 1980s, but the practical implementation of the idea was possible only in the 1990s due to the development of computer technology, telecommunications, as well as encryption and cryptography systems. It was when the need arose and the preconditions for the introduction of electronic money emerged. On the one hand, the developing e-commerce in the Internet information network - a new stage of development and globalization of the world economy - requires electronic money. On the other hand, electronic money is more efficient in terms of labor costs and circulation costs (Table 3.), it enables a faster circulation, compared with the turnover of paper and metal money.

Table 3. Cost of basic transactions on debiting the customer's account (in US Relative dollars) ${ }^{8}$

\begin{tabular}{ll}
\hline Cashing the customer's account at the bank & 1.95 \\
\hline ATM transaction & 0.80 \\
Transaction in telephone banking & 0.60 \\
Transaction by credit card on the Internet & 0.20 \\
Electronic cash transaction & 0.01 \\
\hline
\end{tabular}

\section{Discussion}

Still, the nature of electronic money remains a debatable issue. For example, V. P. Perepechenko believes that "electronic money - is not a new type of money, but the form of the account management in banks, i.e. it is a technical method of registration of non-cash money, saving the relevant information, as well as modern methods of interbank communication".

A similar position is represented in the paper by $\mathrm{O}$. I. Lavrushin, who believes that "the growing popularity of non-cash payments by means of electronic equipment contributed to the emergence of the term "electronic money". In fact, these operations refer to non-cash payments with the only difference that instead of managing cash by means of paper documents (orders, checks, etc.), it is done using electronic technology, through electronic signals" ${ }^{\prime 1}$.

In contrast to the abovementioned approaches, V. Y. Katasonov states that "electronic money includes only those funds that are replacing the credit money issued in the traditional way by the central bank and commercial banks" ${ }^{11}$. V. Y. Katasonov states that "true electronic money exists; it is beyond the banking sector and the control of the central banks; this money is issued by various non-banking institutions - telephone, transport, and trading companies. Such money is used by means of different cards and/or special terminal devices connected with the electronic resources of the issuer, which store and collect data on the users of electronic money. The main distinguishing feature of this money does not relate to the medium (magnetic recording medium), but stems from the fact that it is non-bank money" ${ }^{\prime 1}$. In addition to that, he identifies two main types of electronic money: a) Network money and b) Money created on the basis of cards ${ }^{11}$.

From our perspective, studying the evolution of money in the system of money circulation enables to identify the 
electronic money's role in this process more accurately. We believe that the electronic money into its material form can be defined as a file (special electronic impulses), containing a number that describes the sum its owner possesses, as well as other specific information, generated by the credit institution and stored on storage devices (in memory) of a user's Computer (PC), the data from which are transmitted from one computer to another via telecommunication circuits and other electronic means of data transfer.

From economic perspective, the electronic money is a new type of money - bank notes represented in the form of information in computer memory.

Analyzing the definitions of the "electronic money", we should note that it is not correct to use the term "electronic money" as a synonym for "electronic money transfer", or "debit card", since in this case non-cash money is used in payment, and its type does not change depending on the form of media used (paper or electronic) in the transactions with non-cash money.

In general, electronic money, in our opinion, can be classified according to different criteria: By its circulation (used only on the Internet, used outside computer networks, universal); by the used media (personal computers, chip cards, etc.); by the number of issuers; by the limit on the size of account and payment; depending on the degree of anonymity; by the number of currencies used, etc.

The area of electronic money application is currently expanding. A number of countries aired the intention to gradually withdraw from the cash use on their territory (for example, Norway, Denmark, and the UK). At the same time the basic principles of money use remain unchanged.

The modern world should identify the difference between cash and non-cash electronic money. From our perspective, one should distinguish between "electronic cash" and "electronic non-cash" money. Electronic cash, with all the basic properties of traditional cash (negotiability, no direct link to a bank account, universality, lump-sum and final settlement), at the same time does not possess the disadvantages of traditional cash (high circulation costs, conversion difficulties, the need for special paper, etc). Anonymity is another option of cash, but in this regard it should be noted that using electronic money makes it technically possible to determine the owner of cash which aids fight against the shadow economy.
The only difference between the electronic money from the traditional cash credit money is another physical form of the money media. The nature of money as an economic category, its functions, roles and relationships between parties do not change, it is only the material medium that is subject to alteration.

Electronic money does not take any new place in the modern system of cash and non-cash total money turnover. This type of money, characterized as electronic cash and electronic non-cash due to its intrinsic characteristics, takes its own place in the total money turnover.

Currently, the number of systems based on the electronic money is limited. Among dozens of relatively well-known payment systems dealing with electronic payments we would like to single out the systems using Electronic Cash (e-cash). These systems are supported and developed by a number of major banks and companies of the developed countries. This lets us expect their further expansion in the near future. What's more, the development of e-commerce and its major component - e-retail and services in the Internet, - reveals its positive features: Access to the largest possible corporate and consumer markets; absence of geographical and time obstacles; consumer access to full information on the product or service; online payments; low operating costs etc.

At the same time there are various ways to pay for goods and services in retail e-commerce: Non-cash (by credit card, electronic money transfers, prepaid financial products and electronic checks) as well as in electronic cash.

According to experts' prediction, in the next few years the volume of various indicators (retail sales and services, corporate trading volume, the number of sellers and buyers) is to increase 10-15 times, which indicates both stable and rapid development of the e-commerce. The analysis of the Internet transactions enables to identify the most popular type of goods online - intellectual products (information, services and software), which is currently one of the main economic resources. The specific feature of this product stems from the fact that it is directly transferred from seller to buyer via a computer network, and its cost is often quite small. Thus, the most economical way of payment in this case is the use of electronic money. At the initial stage of electronic money implementation small payments are the most effective sector of the money turnover. Non-cash payments, substituting cash when paying in large sums, are less effective and economical with smaller payments (for sums up to 10-30 dollars), while their number is high. According to the research 
by VISA Int., conducted in 29 countries ( $80 \%$ of world production), about $20 \%$ of annual cash payments are not more than 10 dollars ${ }^{12-13}$.

At present day, however, along with using the electronic money for small payments, due to its universality, it can replace paper money when making larger payments and, thus, narrow traditional sphere of non-cash payments.

The experience of electronic money use has convincingly demonstrated that it is possible to "separate" the money circulation from the central bank as the single emission center. Consequently, we may talk about the emergence of a fundamentally new system of money circulation.

Both Russia and the world have good conditions for decentralized emission of money, the danger of which being the possible loss of the central bank's control over emissions. The latter is not just a matter of economic stability, but also of a country's economic security.

The introduction of electronic money in the money circulation at the global and national levels is associated with a number of problems, including the following:

- National banking system and the existing cashless payment systems are not always prepared for smooth functioning in the new conditions.

- Retail businesses and organizations should be legally compelled to adopt new means of payment - electronic money.

- The public in general does not always adequately perceive upcoming changes; so, it is important to raise the financial awareness of the population.

- During the transition to electronic money payments there is a need for timely support from the legal system since the parties have a large number of questions concerning legal matters.

- Under the conditions of the criminalized shadow economy it is important to overcome the poor transparency (anonymity) of the payment when using electronic money. In this context creating a system of marked money to fight the shadow turnover is becoming a particularly relevant issue.

- Significant effort, time and financial resources, skilled human resources, etc. are required to ensure the security of electronic payments and settlement. Addressing the legal framework for electronic money involves two options: Through a radical change in the legal framework (development and introduction of new legislation) or adaptation of existing legislation.

Russia adopted the Law on the National Payment System which clearly defines the status of electronic money. According to it, this is money that was previously provided by one person to another person for performance of monetary obligation to third parties and to which the person, providing the funds, has the right to give orders only by means of electronic medium of payment, i.e., media and (or) methods that allow the client of the money transfer operator to compile, certify and pass orders for the transfer of funds within the applicable form of noncash payments using information and communication technology, electronic media, including payment cards and other technical devices ${ }^{14}$.

Safety of the electronic payment systems operation can be ensured by various methods: Technical (using secure hardware and software devices, data encryption, user authentication); functional (setting restrictions on the use of electronic money, transactions control, etc.) and legal (legal framework regulating the use of electronic money and imposing liabilities for violation of the law).

An important issue in the implementation of electronic money is its impact on the monetary system. The central banks of issue and regulators of financial markets are the main supervisors and agents of the monetary policy in all countries. Therefore, it is logical that the main difficulty for the organizations implementing an electronic money system is the arrangement of relations with these entities.

The main issues facing central banks today regarding the introduction of electronic money are: the permission to issue electronic money and defining the range of issuers; measuring its influence on the money supply, velocity of money circulation, seigniorage revenues; management of electronic money regulation and circulation; addressing emerging risks in the electronic money systems.

The use of electronic money significantly accelerates the turnover of the monetary unit used in transactions, while there is no corresponding reduction in the money supply. On the contrary, it may partially increase if the emission of electronic money by private lending institutions is not controlled by regulators (central banks, for example). However, at the initial stage of payment systems development that are based on the electronic money, the money supply growth and its impact on the overall velocity of money circulation will not be so large, since a large proportion of the electronic money transactions is carried out in small sums for goods and services of the actual supply and demand.

To solve the problems mentioned above, central banks may limit the range of issuers and establish specific measures to control and regulate the operation of credit institutions, limit the total issue of electronic money, set 
limits on payment transactions, impose certain reserve requirements on issued electronic money or a fee for electronic money issue privilege depending on the volume, monopolize the issue of electronic money, etc.

As a result, the competitive development of various systems of electronic money with a big number of issuers operating under the mandatory supervision of the government regulators is possible only in the countries with developed economies. In these countries there is a stable monetary system along with established practices of payment transactions; that is why electronic money here is to occupy the niche where it can be used most effectively.

In developing countries with a young and yet unstable monetary system, the introduction of electronic money should be under tight control. The number of introduced systems should be limited and unified to the extent possible.

\section{Conclusion}

All the above considered, we can say that the further development of such money function as a medium of exchange is a complicated and contradictory process. There are changes in definitions and characteristics that reflect the essential features of the studied phenomenon. However, money always acts in accord with its current forms under specific historical conditions, i.e., determined by the cumulative actual conditions of its circulation.

The use of electronic equipment in non-cash payments has led to the emergence of electronic money. "Invisible", "non-material" electronic money demonstrates, more clearly than any other type of money, that its nature is associated not only with the material form, but, more importantly, with its ability to perform certain functions. Therefore, from an economic point of view, the history of money is an evolution towards a better performance of their functions with parallel reduction in circulation costs. In this regard, it is necessary to develop international standards for the regulation of electronic money circulation, since its use is largely a new phenomenon - a prototype of a fundamentally new monetary system.

The article points out that the competitive development of various systems of electronic payment and settlement with a large number of issuers should be subject to mandatory supervision of financial regulators. In countries with a developed economy and a stable monetary system, with the established tradition of payment transactions, electronic money will occupy a niche where its use will be most effective. Developing countries with a young and yet unstable monetary system need more control when introducing electronic money.

\section{References}

1. Mikroekonomika [Microeconomics]. Textbook. Moscow: KNORUS; 1999. [in Russian].

2. Finansovo-kreditnyyentsiklopedicheskiyslovar [Financial and Credit Encyclopedic Dictionary]. Gryaznova AG, editor. Moscow: Finansyistatistika; 2002. [in Russian].

3. Rossiyskayabankovskayaentsiklopediya. [Encyclopedia of Russian Banking]. Moscow: ETA; 1995. p. 133-4. [in Russian].

4. Dengi, kredit, banki [Money, Credit, Banks]. Textbook. Beloglazova GN, editor. Moscow: Yurayt; 2006. [in Russian].

5. Dengi, kredit, banki [Money, Credit, Banks]. Textbook. Kulikova AG, editor. Moscow: KNORUS; 2009. [in Russian].

6. Mishkin FS. Ekonomicheskayateoriyadeneg, bankovskogodelaifinansovykhrynkov [Economics of Money, Banking and Financial Markets]. Translated from English, 7th ed. Moscow: Williams Publishing House; 2013. [in Russian].

7. Rose R. Money and Capital Markets. New York: Richard D. Irwin Inc; 2007.

8. Frost and Sullivan. Telecoms Newsletter; 1998 Mar.

9. Perepechenko VP. Dengi, banki, kredit [Money, Banks, Credit]. Textbook. Moscow: Ekonomika; 2008. [in Russian].

10. Dengi, kredit, banki [Money, Credit, Banks]. Textbook. Lavrushin OI, editor. Moscow: KNORUS; 2014. [in Russian].

11. Dengi, kredit, banki [Money, Credit, Banks]. Textbook. Katasonov VY, Bitkov VP, editors. Moscow: Yurayt; 2014. [in Russian].

12. Visa Company Website. Available from: www.visaeurope. com

13. Rynokelektronnykhkoshelkov - vzglyadkompanii VISA [The market of digital wallet - VISA perspective]. World of Cards; 1996; 12:37. [in Russian].

14. Federal Law of 27.06.2011 No. 161-FZ (Revised 12.29.2014). On the National Payment System. (Revised and expanded, entered into force 01.03.2015). Art 3, Paras 18, 19. 